\title{
Ownership Structure and Dividends Policy: Emerging Market Evidence
}

\author{
Ahmad N. Obaidat ${ }^{1}$ \\ ${ }^{1}$ Accounting Department, Business Faculty, Tafila Technical University, Jordan \\ Correspondence: Ahmad N. Obaidat, Accounting Department, Business Faculty, Tafila Technical University, \\ Jordan.
}

Received: March 30, 2018

Accepted: April 24, $2018 \quad$ Online Published: May 9, 2018

doi:10.5539/ibr.v11n6p65

URL: https://doi.org/10.5539/ibr.v11n6p65

\begin{abstract}
This study investigated the effect of ownership structure on the dividend policy of the financial firms listed on Amman Stock Exchange (ASE) for the period 2014-2016. The results indicated a positive relationship between dividend and institutional, managerial, and foreign ownership, and negative relationship between dividend and ownership concentration. The result also indicated that a large portion of the ownership is in the hand of the instructions and the board of directors, and the ownership is not highly concentrated.
\end{abstract}

Keywords: ownership structure, dividend, financial firms, Amman stock exchange

\section{Introduction}

A continuous challenging decision disturbing firms management is to decide the amount of earnings to be distributed to shareholders as dividend and the amount that should be retained. This is considered challenging because it represents a trade-off decision between distributing earnings to satisfy shareholders' needs and retain earnings to finance growth and expansion. Both managers and shareholders are interested in such decision because managers consider the dividend as a positive indicator of their performance, and shareholders consider it as an indicator for their investment worthiness and consequently enables them to take the rational decisions concerning buying, holding, or selling shares. In this regard, Ehsan et al. (2013) and Sáez \& Gutiérrez (2015) argued that dividend policy is one of the most important factors of determining the firms' value.

By reviewing some of the previous related studies (e.g., Erol \& Tirtiroglu, 2011; Lace et al., 2013; Al-Nawaiseh, 2013; Al-Qahtani \& Ajina, 2017), it is noticed that the word "Dividend" was accompanied by the word "Puzzle". This accompanying was due to the difficulty of controlling all possible factors that could affect dividend policy, so some of researchers consider it as a puzzle.

Although the previous studies examined the association between different factors and dividend policy, Erol \& Tirtiroglu (2011) stated that there is still a lot to be done, Al-Nawaiseh (2013) argued that the issues related to why firms pay dividend is not yet resolved, Lace et al. (2013) concluded that the factors previously investigated do not fully explain the changes in the dividend payments, Al-Qahtani \& Ajina (2017) asserted this when they concluded that there is no complete understanding of the factors that affect the dividend policy and the manner in which these factors interact. Among other factors investigated was the ownership structure.

Different types of ownership structures are found in firms (e.g., institutional, managerial, and foreign ownership). Ehsan et al. (2013) and Kulathunga \& Azeez (2016), among others, concluded that these different structures have a variety of influences over the dividend policy.

Agency cost theory has been utilized in explaining the association between ownership structures and dividend policy. The agency cost theory highlights the impact of the conflicts of interest between managers and shareholders, due to the separation between ownership and management, on dividend policy. According to this theory, dividend can be used as a tool to mitigate this conflict by reducing the amount of free cash flow that might be expropriated by management (Setia-Atmaja, 2009; Al-Qahtani \& Ajina, 2017). Different points of views existed in the previous studies regarding the effect of each type of ownership on dividend policy (which will be represented in the next section).

Two main reasons motivated the conduction of this study: first, there are very few studies that investigated the impact of ownership structure on dividend policy in the emerging markets, compared to the developed markets 
(Al-Nawaiseh, 2013; Kulathunga \& Azeez, 2016). Second, according to my best knowledge, all of the local studies (e.g., Warrad et al., 2012; Al-Shubiri et al., 2012; Al-Gharaibeh et al., 2013; Al-Nawaiseh, 2013) investigated the impact of ownership structure on dividend policy in the industrial and the service sectors, and none was conducted on the financial sector. So, this study aims to investigate the impact of different ownership structures (institutional, managerial, foreign and concentration) on dividend policy of the financial firms listed on Amman Stock Exchange (ASE) for the period 2014-2016.

\section{Ownership Structure, Dividend Policy and Hypotheses Development}

\subsection{Institutional Ownership}

Institutional shareholders are characterized by their ability to control the management due to their large size of investments and their professional approach to manage their investments (Lace et al., 2013), so they become the leading player in determining dividend policy (Al-Qahtani \& Ajina, 2017).

Different points of views were found in the previous studies regarding the association between institutional ownership and dividend policy. On the one hand, Han et al. (1999) and Al-Najjar \& Kilincarslan (2016) revealed a negative relationship between dividend payout and institutional ownership due to their ability to effectively monitor the firm's management, which in turn reduces the agency cost and the need for high dividend payouts. On the other hand, Farinha (2003) suggested that institutions may influence the firms to pay higher dividend payouts if they believe that their own direct monitoring efforts are inefficient or too costly.

Accordingly, the first hypothesis could be presented as follows:

H1: Holding all else constant, there is a negative relationship between the institutional ownership and the dividend.

\subsection{Managerial Ownership}

Yi-Hua et al. (2010) and Lace et al. (2013) stated that as the managerial ownership (insider ownership) increases there will be low conflicts of interest between managers and outside shareholders, consequently reducing the agency costs and the need for high dividend payout. Also, Sáez \& Gutiérrez (2015) and Kulathunga \& Azeez (2016) argued that when a large percentage of the shares is in the hands of insiders, they will have the incentives to reduce the dividend payout to retain the cash inside the firm to generate private benefits to themselves, such as enhancement of salaries and bonuses, at the expense of outsiders. On the other hand, Al-Qahtani \& Ajina (2017) believed that the high percentage of managerial ownership leads to an opportunistic behavior among the board of directors that will result in high dividend levels to control this behavior.

Accordingly, the second hypothesis could be presented as follows:

H2: Holding all else constant, there is a negative relationship between the managerial ownership and the dividend.

\subsection{Foreign Ownership}

Chai (2010) found a positive association between foreign ownership and dividend payout level as the foreign shareholders overweight large and profitable firms with high dividend payout rate. In the same context, Lace et al. (2013) stated that foreign shareholders prefer investments in the emerging market firms in case of high dividend opportunity. Le \& Le (2017) also stated that foreign shareholders prefer more dividend payments in the weak corporate governance context because they are disadvantageous in terms of information regarding firms performance and market changes.

On the contrary, Glen et al. (1995) believed that most shareholders in the industrial countries invest in the stocks of emerging markets for their long run growth potential they represent, not for the short-term dividend they will produce, suggesting a negative relationship. Sulong \& Nor (2008) stated that foreign shareholders may prefer a low dividend policy in the case where they can play an active monitoring role to mitigate the potential managerial opportunism and control the agency costs of free cash flow. Al-Najjar \& Kilincarslan (2016) asserted this by stating that foreign shareholders might be efficient in monitoring the management in emerging markets due to their experience and because the foreign ownership increases foreign analysts' interests, which in turn provide additional monitoring on the managements' activities, consequently reduce the agency costs and the need for high dividend payout.

Accordingly, the third hypothesis could be presented as follows:

H3: Holding all else constant, there is a negative relationship between the foreign ownership and the dividend. 


\subsection{Ownership Concentration}

There is general consensus in the previous studies that large shareholders in firms with concentrated ownership structures are considered influential in the determination of dividend policy, which in turn may generate private benefits to them at the expense of the minority shareholders (e.g., Sáez \& Gutiérrez, 2015; Sindhu et al., 2016; Le \& Le, 2017).

Yi-Hua et al. (2010) stated that if the large shareholders fail to realize capital gains from price appreciation of shares, cash dividend becomes their sole source of income. consequently, they have the motivation to ask for large dividend. Kulathunga \& Azeez (2016) also concluded that firms are forced to distribute more dividends to decrease the agency cost when they include ownership concentration.

On the other hand, Khan (2006) and Wei et al. (2017) indicated a negative relationship between ownership concentration and dividend payout. The later justified this by indicating that the large shareholders prefer to retain cash in the firms to reinvest it in more profitable projects.

Accordingly, the fourth hypothesis could be presented as follows:

H4: Holding all else constant, there is a negative relationship between ownership concentration and the dividend.

\section{Literature Review}

Han et al. (1999) examined the relationship between institutional ownership and dividend policy. The results showed a positive correlation between institutional ownership and dividend payout. Khan (2006) investigated the relationship between ownership structure and dividend for 330 large quoted UK firms. The results indicated a negative relationship between dividend and ownership concentration. The results also indicated that the ownership composition affected dividend, where a negative relationship was observed for shareholding by individuals and a positive relationship observed for shareholding by insurance companies. Sakinc \& Gungor (2015) investigated the impact of ownership structure on dividend for 271 real and banking firms listed on Istanbul Stock Exchange between 2004-2011. The results indicated that the cash dividend was associated positively with ownership concentration and negatively with foreign ownership. Kulathunga \& Azeez (2016) investigated the association between ownership structure and dividend policy of listed firms in Colombo Stock Exchange over the period 2006-2014. The results indicated a negative effect of institutional and managerial ownership on dividend, while the ownership concentration showed a positive effect. Sindhu et al. (2016) analyzed the impact of ownership structure on dividend payout ratio of 100 non-financial firms listed on Karachi Stock Exchange for the period 2011-2015. The results indicated that the institutional ownership showed a positive impact on dividend payout ratio, while the managerial ownership showed a negative one. Mossadak et al. (2016) analyzed the relationship between the ownership structure and the dividend policy in Morocco. The results indicated a positive impact of ownership concentration and foreign ownership on dividend, while the institutional ownership did not show any significant relationship with dividend policy. Al-Qahtani \& Ajina (2017) examined the relationship between the ownership structure and dividend payout policy for 100 firms listed on Saudi Stock Market for the period 2012-2015. The results indicated a positive relationship between managerial ownership and dividend. Wei et al. (2017) examined the impact of ownership concentration on dividend payout of Malaysian publicly listed firms for the period 2005-2015. The results indicated that ownership concentration was associated with low dividend payout. Le \& Le (2017) investigated the relationship between the identities and level of shareholdings of the largest shareholders, and cash dividend policy of 180 firms listed on Vietnam stock exchange markets for the period 2009-2013. The results indicated that the firms with foreign investors as the largest shareholders had higher dividend payout ratio than firms with domestic investors as the largest shareholders. The results also indicated that the higher the level of holdings, by the largest shareholders, is the lower the dividend payout will be.

In the local context, Warrad et al. (2012) examined the association between ownership structure and dividend policy of the industrial public shareholding firms for the period 2005-2007. The results indicated a positive relationship between foreign ownership structure and the dividend payout. Al-Shubiri et al. (2012) examined the association between ownership structure and dividend policy of the industrial firms for the period 2005-2009. The results indicated a negative relationship between the institutional ownership and dividend per share. The results also indicated that the higher the ownership of the five largest shareholders, is the higher the dividend per share will be. Al-Gharaibeh et al. (2013) investigated the effect of ownership structure on the dividend policy for 35 industrial and service firms for the period 2005-2010. The results indicated a positive association between institutional ownership and dividend, and negative association between managerial ownership and dividend. Al-Nawaiseh (2013) investigated whether ownership structure affect dividend policy of the industrial firms for the period 2000-2006. The results indicated a positive association between institutional ownership and dividend, and negative association between managerial ownership and dividend. 


\section{Methodology}

\subsection{Sample and Data Collection}

The study sample consisted of (64) firms, representing all the financial firms listed on ASE for the period 2014-2016. These firms include (15) banks, (20) insurance firms, and (29) financial services firms. Dividend data and ownership information were collected from the firms' annual reports and the Security Depository Center (SDC) online database.

\subsection{Measurement of Variables}

Following (Al-Shubiri et al., 2012 and Kulathunga \& Azeez, 2016), dividend, which represent the dependent variable, was measured by cash dividend per share and was calculated by dividing the total cash dividend distributed by the number of shares outstanding. Although dividend could be measured by the dividend yield or payout ratio, this study used the dividend per share as a measure of dividend policy to overcome the possible problems associated with the use of the other measures. On the one hand, because dividend yield is measured by dividing dividend per share by the closing market price per share, this measure is affected by factor (i.e., share market price) other than the dividend. On the other hand, because the dividend payout ratio is measured by dividing the total dividend paid by the net income, there is a probability of negative payout ratio if the earnings is negative (loss) or a probability of an overstated payout ratio if the earnings is low.

Four types of ownership structure represented the independent variables in this study (institutional, managerial, foreign and concentration). Institutional ownership was measured as the percentage of the shares held by the institutional shareholders (e.g., mutual funds, pension funds, banks), whether domestic or foreign (Kulathunga \& Azeez, 2016). Managerial ownership was measured as the percentage of the shares directly held by the board of directors of the firm (Sulong \& Nor, 2008). Foreign ownership was measured as the percentage of the shares held by the foreign shareholders whether individuals or institutional (Chai, 2010; Al-Najjar \& Kilincarslan, 2016). Ownership concentration was measured by using the Herfindahl Index (HFI) which is equal to the sum of the square of the top five shareholders' holding percentages (Yi-Hua et al., 2010; Kulathunga \& Azeez, 2016).

\section{Results and Discussion}

Table 1 presents the descriptive statistics for the ownership structure and dividend for the sample firms during the study period. As shown, more than half (about 51\%) of the ownership is in the hands of institutions, with a range from $(0.2 \%)$ to $(100 \%)$. Managerial ownership results indicate that about (46\%) of the ownership is in the hands of the board of directors of these firms. These results indicated that the outside individual (minority) shareholders have a small percentage of ownership.

In the local context, Al-Gharaibeh et al. (2013) found closer percentages of the institutional and managerial ownership in the industrial and the service firms listed on ASE for the period 2005-2010; they found that about $(52 \%)$ of the ownership is in the hands of institutions and about (47\%) of the ownership is in the hands of the board of directors.

The results also indicate that about (28\%) of the ownership is in the hands of foreign shareholders, whether individuals or institutions, (19\%) of the ownership is in the hands of the largest five shareholders, whether individuals or institutions, suggesting that the share ownership in the financial firms is not highly concentrated.

The average cash dividend distributed by the sample firms is about (0.067) per share, with a minimum distribution of (zero) for the firms that did not distribute any cash dividend during the study period, and a maximum distributions of (0.455) per share, indicating huge differences between firms in terms of dividend payments. In the local context, Al-Shubiri et al. (2012) revealed that the average cash dividend distributed by the industrial firms listed on ASE is about 0.041 per share, for the period 2005-2009.

Table 1. Descriptive Statistics*

\begin{tabular}{lcccc}
\hline Variable (Ownership) & Mean & SD & Min & Max \\
\hline Institutional & 0.512 & 0.281 & 0.002 & 1.000 \\
Managerial & 0.461 & 0.244 & 0.003 & 0.964 \\
Foreign & 0.282 & 0.272 & 0.000 & 0.906 \\
Concentration & 0.190 & 0.192 & 0.024 & 0.821 \\
Dividend ** & 0.067 & 0.095 & 0.000 & 0.455 \\
\hline
\end{tabular}

$*$ Values rounded to the third decimal.

** Values in US dollars.

Table 2 presents Pearson correlation matrix among the study variables. As shown, the correlation coefficients 
indicate the non-existence of multicollinearity problem between them. Dividend is significantly correlated positively with institutional, managerial, and foreign ownership, while the ownership concentration shows a positive but insignificant correlation with dividend. The results also indicated a positive significant correlation between all types of ownership.

Table 2. Pearson Correlations Matrix

\begin{tabular}{lccccc}
\hline Variable (Ownership) & Institutional & Managerial & Foreign & Concentration & Dividend \\
\hline Institutional & 1.000 & & & & \\
Managerial & $0.606^{* *}$ & 1.000 & & & \\
Foreign & $0.515^{* *}$ & $0.294^{* *}$ & 1.000 & & \\
Concentration & $0.621^{* *}$ & $0.551^{* *}$ & 0.629 & 1.000 & \\
& & & $* *$ & & \\
& & $0.275^{*}$ & 0.333 & & \\
Dividend & $0.332 * *$ & & $* *$ & 0.050 & \\
\hline
\end{tabular}

* $\quad$ Significant at $\mathrm{p}<0.05$ level

** Significant at $\mathrm{p}<0.01$ level

The multivariate regression analysis was performed to empirically test the study hypotheses. The regression model that was performed and tested is as follows:

$$
\operatorname{Div}_{i}=\beta_{0}+\beta_{1} \operatorname{Ins}_{i}+\beta_{2} \operatorname{Man}_{i}+\beta_{3} \text { For }_{i}+\beta_{4} \operatorname{Con}_{i}+\varepsilon_{i}
$$

Where:
$D i v_{i} \quad$ : Continuous variable represents the cash dividend per share,
Ins $s_{i} \quad$ Continuous variable represents the percentage of institutional ownership,
$\operatorname{Man}_{i}$ : Continuous variable represents the percentage of managerial ownership,
For $_{i}$ : Continuous variable represents the percentage of foreign ownership,
$\mathrm{Con}_{i}$ : Continuous variable represents the percentage of ownership concentration.

Table 3 presents the results of multivariate regression analysis. The adjusted $\mathrm{R}$ square result indicated that about (24.8\%) of the variance in the dividend is explained by the model, ANOVA results indicated that this model is a statistical significant predictor of the outcome $(\mathrm{p}<0.05)$. The coefficients of the institutional, managerial, and foreign ownership are positively statistically significant, while the coefficient of the ownership concentration is negatively statistically significant $(\mathrm{p}<0.10)$. Beta results indicated that the ownership concentration followed by foreign ownership have the strongest contribution in explaining the dividend outcome. Finally, the values of Tolerance and VIF in the collinearity statistics provide additional support about the non-existence of multicollinearity problem.

Therefore, these results provide support for rejecting the first three hypotheses and accepting the fourth one, where the first three hypotheses proposed a negative relationship between the dividend and the institutional ownership, the managerial ownership, and the foreign ownership, respectively; while the fourth hypothesis proposed a negative relationship between the dividend and the ownership concentration.

The result regarding the positive relationship between institutional ownership and dividend confirms the results of Han et al. (1999) study in USA, Al-Gharaibeh et al. (2013) study in Jordan, and Sindhu et al. (2016) study in Pakistan. The result regarding the positive relationship between managerial ownership and dividend confirms the results of Al-Qahtani \& Ajina (2017) in Saudi Arabia. The result regarding the positive relationship between foreign ownership and dividend confirms the results of Warrad et al. (2012) study in Jordan, Mossadak et al. (2016) study in Morocco, and Le \& Le (2017) study in Vietnam. The result regarding the negative relationship between ownership concentration and dividend confirms the results of Khan (2006) study in UK and Wei et al. (2017) study in Malaysia. 
Table 3. Multivariate Regression Analysis Results

\begin{tabular}{|c|c|c|c|c|c|c|c|c|c|}
\hline & \multicolumn{2}{|c|}{ Unstandardized } & \multirow{3}{*}{ Beta } & \multirow{3}{*}{$\mathrm{t}$} & \multirow{3}{*}{ Sig. } & \multirow{3}{*}{$\begin{array}{l}\text { Lower } \\
\text { Bound }\end{array}$} & \multirow{3}{*}{$\begin{array}{l}\text { Upper } \\
\text { Bound }\end{array}$} & \multicolumn{2}{|c|}{ Collinearity } \\
\hline & \multicolumn{2}{|c|}{ Coefficients } & & & & & & $\underline{\text { Statis }}$ & \\
\hline & B & Sta. Error & & & & & & lolerance & $\mathrm{VIF}$ \\
\hline Constant & -.023 & .025 & & -.943 & .350 & -.072 & .026 & & \\
\hline Institutional & .091 & .053 & .270 & 1.714 & .092 & -.015 & .197 & .480 & 2.083 \\
\hline Managerial & .112 & .056 & .289 & 1.985 & .052 & -.001 & .224 & .564 & 1.774 \\
\hline Foreign & .163 & .051 & .468 & 3.204 & .002 & .061 & .264 & .560 & 1.786 \\
\hline Concentration & -.281 & .082 & -.571 & -3.434 & .001 & -.445 & -.117 & .432 & 2.315 \\
\hline \multicolumn{10}{|c|}{ Model Summary } \\
\hline & $\mathrm{R}$ & R Square & \multicolumn{2}{|c|}{$\begin{array}{l}\text { Adjusted R } \\
\text { Square }\end{array}$} & \multicolumn{3}{|c|}{ Std. Error of the Estimate } & & \\
\hline & .544 & .296 & & & & .082 & & & \\
\hline & $\begin{array}{c}F \\
6.202\end{array}$ & $\begin{array}{l}\text { Sig. } \\
.000\end{array}$ & & & & & & & \\
\hline
\end{tabular}

\section{Conclusion}

This study investigated the effect of ownership structure on the dividend policy of the financial firms listed on Amman Stock Exchange (ASE) for the period 2014-2016. It particularly investigated the effect of institutional ownership, managerial ownership, foreign ownership, and ownership concentration on the dividend per share for a sample of (64) firms representing all financial firms listed on ASE.

The main results revealed by this study indicated a positive relationship between dividend per share and institutional, managerial, and foreign ownership, and a negative relationship with ownership concentration. Several possible justifications for these results were found in the previous studies, Farinha (2003) stated that the institutional shareholders may influence the firms to pay higher dividend if they believe that their own direct monitoring efforts are inefficient or too costly, Al-Qahtani \& Ajina (2017) argued that the high percentage of managerial ownership leads to an opportunistic behavior among the board of directors that will result in high levels of dividend to control this behavior, Le \& Le (2017) stated that the foreign shareholders prefer more dividend payments in the weak corporate governance context because they are disadvantageous in terms of information regarding firms performance and market changes; while Wei et al. (2017) stated that large shareholders prefer to retain cash in firms to be reinvested in more profitable projects.

The study also revealed secondary results. First, a large portion of the ownership in financial firms is in the hands of the institutions and the board of directors, confirming the results of Al-Gharaibeh et al. (2013) study that was conducted on the industrial and service firms listed on ASE. Second, the ownership in financial firms is not highly concentrated, only (19\%) of the ownership is in the hand of the largest five shareholders.

In light of these findings, and in the absence of a comprehensive local study, this study recommend the conducting of a comprehensive comparative study that will cover all sectors in ASE; in addition, the investigation of other potential factors (e.g., earnings, liquidity, cash flows, and financial leverage) that may have an effect on the dividend policy.

\section{References}

Al-Gharaibeh, M., Zurigat, Z., \& Al-Harahsheh, Z. (2013). The Effect of Ownership Structure on Dividends Policy in Jordanian Companies. Interdisciplinary Journal of Contemporary Research in Business, 4(9), 769-796.

Al-Najjar, B., \& Kilincarslan, E. (2016). The effect of ownership structure on dividend policy: Evidence from Turkey. Corporate Governance: the International Journal of Business in Society, 16(1), 135-161. https://doi.org/10.1108/CG-09-2015-0129

Al-Nawaiseh, M. (2013). Dividend Policy and Ownership Structure: An Applied Study on Industrial Companies in Amman Stock Exchange. Journal of Management Research, 5(2), 83-106. https://doi.org/10.5296/jmr.v5i2.2920

Al-Qahtani, T. H., \& Ajina, A. (2017). The Impact of Ownership Structure on Dividend Policy the Evidence from Saudi Arabia. Journal of Emerging Issues in Economics, Finance and Banking, 6(1), 2187-2202. 
Al-Shubiri, F. N., Al-Taleb, G., \& Al-Zoued, A. (2012). The Relationship between Ownership Structure and Dividend Policy: An Empirical Investigation. Review of International Comparative Management, 13(4), 644-657.

Chai, D. H. (2010). Foreign corporate ownership and dividends. Working Paper No. 401. Centre for Business Research, University of Cambridge.

Ehsan, S., Tabassum, N., \& Nasir, R. (2013). Insider and Individual Ownership Structure Influence on Dividend Payout Policy of the Firms: (A case from Pakistan's KSE 100 index Listed Firms). Proceedings of the Northeast Business \& Economics Association, 2013, 73-76.

Erol, I., \& Tirtiroglu, D. (2011). Concentrated Ownership, No Dividend Payout Requirement and Capital Structure of REITs: Evidence from Turkey. Journal of Real Estate Finance \& Economics, 43(1/2), 174-204. https://doi.org/10.1007/s11146-010-9242-7

Farinha, J. (2003). Dividend Policy, Corporate Governance and the Managerial Entrenchment Hypothesis: An Empirical Analysis. Journal of Business Finance \& Accounting, 12, 1173-1209. https://doi.org/10.1111/j.0306-686X.2003.05624.x

Glen, J. D., Karmokolias, Y., Miller, R. R., \& Shah, S. (1995). Dividend policy and behavior in emerging markets : to pay or not to pay. International Finance Corporation discussion paper, no. IFD 26, IFC working paper series. Washington, D.C., The World Bank.

Han, K. C., Lee, S. H., \& Suk, D. Y. (1999). Institutional Shareholders and Dividends. Journal of Financial and Strategic Decisions, 12(1), 53-62.

Khan, T. (2006). Company Dividends and Ownership Structure: Evidence from UK Panel Data. Economic Journal, 116(510), C172-C189. https://doi.org/10.1111/j.1468-0297.2006.01082.x

Kulathunga, K. M. K. N. S., \& Azeez, A. A. (2016). The Impact Of Ownership Structure On Dividend Policy: Evidence From Listed Companies In Sri Lanka. Annual International Conference on Qualitative \& Quantitative Economics Research, 2016, 80-88. https://doi.org/10.5176/2251-2012_QQE16.43

Lace, N., Bistrova, J., \& Kozlovskis, K. (2013). Ownership Type Influence on Dividend Payments in CEE Countries. Business: Theory and Practice, 14(3), 259-266. https://doi.org/10.3846/btp.2013.27

Le, T. V., \& Le, T. H. (2017). Ownership and identities of the largest shareholders and dividend policy: Evidence from Vietnam. Organizations \& Markets in Emerging Economies, 8(1), 86-104.

Mossadak, A., Fontaine, R., \& Khemakhem, H. (2016). The Relationship between Ownership Structure and Dividend Policy in an Emerging Market: A Moroccan Study. Universal Journal of Accounting and Finance, 4(2), 89-95. https://doi.org/10.13189/ujaf.2016.040205

Sáez, M., \& Gutiérrez, M. (2015). Dividend Policy with Controlling Shareholders. Theoretical Inquiries in Law, 16(1), 107-130. https://doi.org/10.1515/til-2015-006

Sakinc, I., \& Gungor, S. (2015). The Relationship between Ownership Structure and Dividend: An Application in Istanbul Stock Exchange. Journal of Economics and Development Studies, 3(4), 19-30. https://doi.org/10.15640/jeds.v3n4a3

Setia-Atmaja, L. Y. (2009). Governance Mechanisms and Firm Value: The Impact of Ownership Concentration and Dividends. Corporate Governance: An International Review, 17(6), 694-709. https://doi.org/10.1111/j.1467-8683.2009.00768.x

Sindhu, M. I., Hashmi, S. H., \& Ul Haq, E. (2016). Impact of ownership structure on dividend payout in Pakistani non-financial sector. Cogent Business \& Management, 3(1). https://doi.org/10.1080/23311975.2016.1272815

Sulong, Z., \& Nor, F. M. (2008). Dividends, ownership structure and board governance on firm value: empirical evidence from Malaysian listed firms. Malaysian Accounting Review, 7(2), 55-94.

Warrad, L., Abed, S., Khriasat, O., \& Al-Sheikh, I. (2012). The Effect of Ownership Structure on Dividend Payout Policy: Evidence from Jordanian Context. International Journal of Economics and Finance, 4(2), 187-195. https://doi.org/10.5539/ijef.v4n2p187

Wei, K. T. I., Qian, L. K., \& Somosundaram, K. (2017). Ownership Concentration, Dividend Payout and Firm Performance: The Case of Malaysia. Malaysian Journal of Economic Studies, 54(2), 269-280.

Yi-Hua, L., Jeng-Ren, C., \& Yenn-Ru, C. (2010). Ownership Structure and Dividend Preference: Evidence from 
China's Privatized State-Owned Enterprises. Emerging Markets Finance \& Trade, 46(1), 56-74. https://doi.org/10.2753/REE1540-496X460106

\section{Copyrights}

Copyright for this article is retained by the author(s), with first publication rights granted to the journal.

This is an open-access article distributed under the terms and conditions of the Creative Commons Attribution license (http://creativecommons.org/licenses/by/4.0/). 